Review Article

\title{
AN OVERVIEW ON PLANTS WITH ANTI-INFLAMMATORY POTENTIAL
}

\author{
KARALE PUSHPA ${ }^{*}$, KARALE MAHESH ${ }^{2}$
}

${ }^{1}$ School of Pharmacy, Swami Ramanand Teerth Marathwada University, Nanded 431606, India, ${ }^{2}$ School of Life Sciences, Swami Ramanand Teerth Marathwada University, Nanded 431606, India

Email: pushpakarale7711@gmail.com

Received: 19 May 2017, Revised and Accepted: 22 Jul 2017

\begin{abstract}
Inflammation is a protective mechanism of the body which involves vascular tissues, plasma proteins or cells and chemical mediators for the removal of hazardous stimuli like pathogens, allergens, irritants or cell damage and initiates the healing process. Anti-inflammatory drugs like steroidal and non-steroidal anti-inflammatory drugs are used to treat inflammation. Recently, the synthetic drugs shows a number of side effects such as kidney failure, ulceration and bleeding, liver damage etc. Therefore a search for the other substitute with no or less side effects is necessary. Plants are used from ancient times to treat various serious disorders. Plant constitutes a large number of chemicals which are responsible for the treatment of disease in an archaistic manner. The present review was pile up various plants with anti-inflammatory potential.
\end{abstract}

Keywords: Inflammation, Medicinal plants, Anti-inflammatory potential

(C) 2017 The Authors. Published by Innovare Academic Sciences Pvt Ltd. This is an open access article under the CC BY license (http://creativecommons.org/licenses/by/4.0/) DOI: http://dx.doi.org/10.22159/ijcpr.2017v9i5.22127

\section{INTRODUCTION}

Inflammation is a protective reaction to tissue damage and involves a complex process of enzyme activation, release of chemical mediators, fluid recruitments, cell migration, tissue damage and healing [1]. Increasing vascular permeability, protein denaturation and membrane alterations are the complex processes, which is associated with pain, fever, swelling and redness [2]. Various harmful stimuli such as pathogens, irritants and chemicals initiate the vascular response. As inflammation is the protective mechanism which removes hazardous stimuli but if inflammation is not treated it leads to diseases like rheumatoid arthritis, atherosclerosis and vasomotor rhinorhoea [3]. In the inflammatory process important role played by chemical mediators that tends to direct the inflammatory response. The mediators produced by plasma proteins or cells including mast cell, neutrophils, platelets, monocytes and macrophages and they bind to specific receptors and produces vascular permeability, neutrophil chemotaxis, smooth muscles contraction and various enzymatic activities [4]. Histamine, leukotrienes, tumor necrosis factor, prostaglandins, serotonin and cytokines are the chemical mediators mostly responsible for inflammatory response.

The most of the inflammation treated by using the synthetic drugs like non steroidal anti-inflammatory drugs and opioids but in current days these are not useful to treat all cases of inflammation due to their potent side effects [5]. As a result, a search for the other alternatives with less side effects and potency seems crucial and advantageous. The medicinal plants have a number of chemical constituents from which novel antiinflammatory agents can be discovered. Research on biological activities of plants yields a number of compounds for the development of modern drugs during the past two centuries [6]. The study of plants that have been traditionally for curing inflammation is still fruitful and logical research strategy in the source of new anti-inflammatory drugs [7]. The aim of present study was to compile data on plants or herbal medicines with anti-inflammatory potential.

\section{Plants with anti-inflammatory potential}

Screening by in vitro models

\section{Zizyphus spina}

The alcoholic extract of the dry powdered seeds and fruits of Z. spina was investigated by protein denaturation method. The result designated anti-inflammatory activity of both parts of the plant extract was significant and comparable with the standard antiinflammatory drug, diclofenac [8].

\section{Solanum xanthocarpum}

The anti-inflammatory activity of stem and leaf extracts of Solanum xanthocarpum was performed by using HRBC membrane lysis method. The prevention of hypotonicity induced HRBC membrane lysis was taken as a measure of the anti inflammatory activity. The anti-inflammatory activity of the ethanol extracts of stem and leaves were compared to that of the standard drug hydrocortisone. Leaf extract at a concentration of $12.0 \mathrm{mg} / \mathrm{ml}$ illustrated maximum protection of HRBC (73.66 $\pm 1.45 \%)$ in hypotonic solution [9].

\section{Aervalanata}

The in-vitro anti-inflammatory activity of Avera lanata was studied by HRBC lysis and protein denaturation method against diclofenac sodium as standard drug. There was a concentration dependent inhibition of lysis of HRBC and protein denaturation by the A. lanata extract and the effect of diclofenac sodium was found to be less when compared with the ethanol extract [10].

\section{Zingiber Officinale}

The Ethanolic extract of ginger was evaluated for in vitro antiinflammatory potential using proteinase inhibitory assay against aspirin as standard drug. The ethanolic extract of ginger showed in vitro antiinflammatory potential by inhibiting (78.49\%) proteinase activity [11].

\section{Thymus vulgaris}

The methanolic extract of Thymus vulgaris was evaluated by LOX assay for it's in vitro anti-inflammatory potential. Thymus vulgaris extract showed the highest total phenolic content which is responsible for anti-inflammatory activity [12].

\section{Plumeriarubra}

The ethanolic extract of fresh flowers was evaluated for antiinflammatory activity by using HRBC membrane stabilization method and inhibition of albumin denaturation method. The results revealed a concentration dependent increase in anti-inflammatory potential [13].

\section{Bauhinia purpurea}

Petroleum ether and methanolic extracts of stem bark of $B$. purpurea were subjected for in vitro anti-inflammatory potential by using protein denaturation and membrane stabilization methods. The highest concentration of extract showed effective anti-inflammatory potential [14]. 


\section{Mangifera indica}

Methanol and ethanol leaf extracts of $M$. indica were investigated for their in vitro anti-inflammatory proprieties by HRBC membrane stabilization method compared to diclofenac as standard. The prevention of hypotonocity induced HRBC membrane lysis was taken as a measure of anti inflammatory activity. The methanolic extract of Mangifera indicaat $100 \mu \mathrm{g} / \mathrm{ml}$ is $15.2 \%$ and at a concentration, $200 \mu \mathrm{g} / \mathrm{ml}$ is $19.2 \%$ shows the highest anti inflammatory activity [15].

\section{Gliricidiasepium}

The anti-inflammatory activity of aqueous extract of Gliricidiasepium flowers by in vitro model by HRBC membrane stabilization assay. Aqueous extract showed dose dependant anti-inflammatory activity in human red blood cell membarane stabilization method at different concentrations $(100-500 \mu \mathrm{g} / \mathrm{kg})$ with a percentage protection of $7.15,11.25,22.71,24.83$ and 26.95 compared to standard diclofenac $32.09 \%$ at $10 \mu \mathrm{g} / \mathrm{kg}$ [16].

\section{Bulbophyllum Kaitense}

Petrolieum ether chloroform, ethanol and aqueous extracts of Bulbophyllum Kaitesnse were tested human red blood cell membrance stabilization method. The plant extract showed significant activities in both of the anti-inflammatories says as compared to diclofenac drug dependent manner. This investigation suggests that ethanolic extract has anti-inflammatory potential activity [17]

\section{Justiciabetonica}

The ethanolic extract of the whole plant of Justiciabetonica was evaluated by HRBC membrane stabilisaton assay. Diclofenac sodium was used as standard drug. The extract exhibited membrane stabilization effect by inhibiting hypo tonicity induced lysis of erythrocyte membrane. Ethanolic extract of Justiciabetonica prevents hypo tonicity induced membrane lysis to an extent of $83.11 \%$ at the concentration of $500 \mu \mathrm{g} / \mathrm{ml}$ [18].

\section{Mimusopselengi}

The methanolic extract of leaves of $M$. elengi was studied by using HRBC membrane stabilization method. It has been reported that certain saponins and flavonoids exerted profound stabilizing effecton lysosomal membrane. The methanolic extract of leaves which showed positive tests for phenolics and flavonoids exhibited the highest membrane stabilizing the activity of $69.13 \pm 0.78$ compared to that of standard diclofenac potassium which exhibited87.89 $\pm 0.69 \%$ protection at $100 \mu \mathrm{g} / \mathrm{ml}$ concentrations [19].

\section{Screening by in vivo models}

\section{Rauvolfiatetraphylla}

Hydro-alcoholic, methanolic, ethyl acetate and hexane extract of Rauvolfiatetraphylla root bark were studied in carrageen an induced acute inflammation in rats. In carrageen, an induced inflammation model, hydro-alcoholic and methanolic extract of $R$. tetraphylla root bark at three different doses produced significant $(\mathrm{P}<0.001)$ reduction when compared to vehicle treated control group and hexane, ethyl acetate extracts [20].

\section{Cassia auriculata}

The anti-inflammatory activity of aqueous, methanolic, ethyl acetate and hydro alcoholic extracts of Cassia auriculata leaves using carrageen an induced paw model. Indomethacin $(10 \mathrm{mg} / \mathrm{kg})$ was used as reference compound in the present study. Among all extracts methanolic extract showed maximum anti-inflammatory potential due to the presence of alkaloids, flavonoids, tannin and steroids [21].

\section{Cyathoclinelyrata}

The chloroform extracts of whole part of Cyathoclinelyrata was evaluated by carrageen an induced hind paw edema and formalin induced paw edema method for its anti-inflammatory potential. The results suggest that the chloroform extracts of the whole part of Cyathoclinelyratac as posses anti-inflammatory potential [22].

\section{Basellaalba}

The methanolic extract of $B$. alba leaf was studied by using cotton pellet induced inflammation and In the carrageen an induced inflammation models. The plant extract has been shown a significant activity at $500 \mathrm{mg} / \mathrm{kg}$ dose $(\mathrm{p}<0.001)$ which was comparable with the standard drug. It can be concluded that Basellaalba possesses a good anti-inflammatory activity [23].

\section{Brideliamicrantha}

The anti-inflammatory potential of methanol extracts of leaf of Brideliamicrantha evaluated by using acute, sub-acute and chronic models of inflammation in Wistar rats. In the carrageenan-induced acute inflammation model, $400 \mathrm{mg} / \mathrm{kg}$ of extract produced $71.79 \%$ edema inhibition. In the histamine induced rat paw edema model, the extract exhibited $72.97 \%$ protection at $400 \mathrm{mg} / \mathrm{kg}$. In the sub-acute model using formaldehyde-induced paw edema, $400 \mathrm{mg} / \mathrm{kg}$ of extract showed

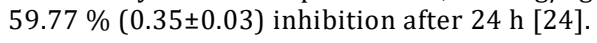

\section{Vitexagnus}

The petroleum ether, ethyl acetate, methanol and aqueous extracts of leaves were subjected to standard acute, sub acute and chronic models of inflammation at 200 and $400 \mathrm{mg} / \mathrm{kg}$. All extracts produced significant inhibition while methanol extract at $400 \mathrm{mg} / \mathrm{kg}$ caused a maximum inhibition of $43 \%$ in paw edema, $75 \%$ inhibition in sub acute and $59.28 \%$ inhibition in the chronic inflammation model. It was concluded that the antiinflammatory activity might be due to flavonoids in the extracts and plant regulates the inflammation by a significant decrease of TNF- $\alpha$ and IL- 6 by macrophages [25].

\section{Dendrophthoe falcate}

The ethanolic, aqueous, chloroform and petroleum ether extracts of D. falcata leaves were illustrated by using carrageen an-induced paw edema model. The highest anti-inflammatory potential of $90.24 \%$ inhibition of paw edema volume was showed by petroleum ether extract at $200 \mathrm{mg} / \mathrm{kg}$ dose. Ibuprofen was treated as a standard drug at $10 \mathrm{mg} / \mathrm{kg}$ body weight [26].

\section{Smilax wightii}

The $S$. wightii fruit extract was evaluated for the antiinflammatory potential by using carrageen an induced paw edema. $S$. wightii exhibited the significant anti-inflammatory activity at the dose of $100 \mathrm{mg} / \mathrm{kg}$ and $200 \mathrm{mg} / \mathrm{kg}$, body weight. The per cent inhibition of paw oedema of $S$. wightii was 59.77 and 77.58 at various doses [27].

Table 1: List of plants with anti-inflammatory potential screened by in vivo models

\begin{tabular}{llll}
\hline Plant name & Plant parts & Extracts & Screening model \\
\hline Dracaena cinnabari & Resin & Methanol & CIPE \\
Partheniumcamphora & Whole plant & Aqueous, ethanol & CIPE \\
Ficusvirens & Bark & Ethanol & CIPE \\
Tragiacannabina & Whole plant & Methanol, chloroform & CIPE \\
Prenanthessarmentosus & Leaves & Chloroform, & CIPE \\
Ixoracoccinea & Flower & Methanol & CIPE \\
Melia azedarach & Seed & Hexane & CIPE, FIPE \\
Rotula aquatic & Whole plant & Pet ether, ethyl acetate, ethanol & CIPE, CPG \\
Cuscutareflexa & Stem & Alcoholic, aqueous & HIPE \\
\hline
\end{tabular}




\begin{tabular}{llll}
\hline Murdannialoriformis & Whole plant & Ethanol & CIPE, CPG \\
Kalanchoepinnata & Stem & Aqueous, ethanol & CIPE \\
Ziziphusxylopyrus & Stem bark & Chloroform, methanol & CIPE \\
Coriandrumsativum & Leaves & Ethanol & CIPE \\
Syzygiumsamarangense & Leaves & Methanol & CIPE \\
Ixorapavetta & Leaves & Ethanol & CIPE \\
Ocimum sanctum & Leaves & Aqueous & CIPE \\
Murrayakoenigii & Root & Pet ether, ethyl acetate, chloroform & CIPE \\
Vitexnegundo & Leaves & Hydroalcoholic & CIPE \\
Antidesmamenasu & Leaves & Aqueous & CIPE, CPG \\
Sapinduslaurifolius & Leaves & Methanol & [41] \\
Corallocarpusepigaeus & Rhizome & Methanol, ethyl acetate & FIPE \\
Solanum melongena & Leaves & Aqueous & CIPE \\
\hline
\end{tabular}

CIPE: Carrageen an Induced Paw Edema; CPG: Cotton Pellet Granuloma; FIPE: Formalin Induced Paw Edema; HIPE: Histamine Induced Paw Edema.

\section{DISCUSSION}

The therapeutic use of herbal medicine increased from past decades due to the side effects of synthetic drugs. Herbal medicines as the major remedy in the traditional system of medicine have been used in medical practice from ancient timings [50]. Ayurveda the "Science of Life" is the holistic alternative science from India. Herbs are staging a comeback over the globe. Ayurveda said to be a world medicine is the most holistic or comprehensive medical system available. The herbal products are safe in contrast to synthetic drugs that are regarded as unsafe to the human body and environment [51]. Inflammation is the protective mechanism of the body that helps to protect itself from injury, allergens, toxins, irritants and chemicals. Now a day whole world moves towards herbal medicines with minimum side effects and cost effective for the treatment of such ailments. There are a number of studies evaluate the anti-inflammatory potential of plants but very few leads towards clinical studies.

\section{CONCLUSION}

The present review outline the varies new anti-inflammatory plants for the discovery and development of novel medicines with less side effects, cost effective and more effective for the treatment of inflammatory disease. This study will helpful to researchers in the future to improve the status and to determine which constituents are effective which will providing clues and developing new antiinflammatory drugs. All the plants involve in the review are studied by pre-clinical methods and it will helpful to the clinical organization to improve the research and innovation of anti-inflammatory drug.

\section{ACKNOWLEDGEMENT}

The authors would like to acknowledge Prof. S. C. Dhawale for providing facilities and guidance in university premises for this review.

\section{CONFLICT OF INTERESTS}

Declare none

\section{REFERENCES}

1. Vane JR, Botting RM. New insights into the mode of action of anti-inflammatory drugs. Inflammation Res 1995;44:1-10.

2. Umapathy E, Ndebia EJ, Meeme A, Adam B, Menziura P, NkehChungag BN, et al. An experimental evaluation of Albucasetosa aqueous extract on membrane stabilization, protein denaturation and white blood cell migration during acute inflammation. J Med Plant Res 2010;4:789-95.

3. Henson PM, Murphy RC. Mediators of the inflammatory process. Amsterdam Elsevier; 1989. p. 404.

4. Smith GR, Sortins M. Cancer, inflammation and the AT 1 and AT 2 receptors. J Inflammation 2004;1:1-3.

5. Ahmadiani A, Fereidoni M, Semnanian S, Kamalinejad M, Saremi S. Antinociceptive and anti-inflammatory effects of Sambucusebulus rhizome extract in rats. J Ethnopharmacol 1998;61:229-32.

6. Arivazhagan S, Balasenthi S, Nagini S. Antioxidant and antiinflammatory activities of Mallotusoppostifolium. J Phytother Res 2000;14:291-3.

7. Kumarappan CT, Chandra R, Mandal SC. Anti-inflammatory activity of Ichnocarpusfrutescens. Pharmacologyonline 2006;3:201-6.
8. Fatma A, Shah AK, Aftab A. Determination of total phenol, in vitro antioxidant and anti-inflammatory activity of seeds and fruits of Zizyphus spina-christi grown in Oman. Asian Pac J Trop Biomed 2014;4(Suppl 2):S656-60.

9. Vijaya PP, David W, Aswan Ali AM, Yogananth N, Syed Ali M, Anuradha $\mathrm{V}$, et al. Evaluation of in vitro anti-inflammatory and antimicrobial properties of Pergulariadaemia and Solanum xanthocarpum. Int J Curr Microbiol Appl Sci 2013;2:94-9.

10. Vivek D, Nimisha GN, Anju MP, Bijesh Vatakkeel, Siju EN, Aiswarya Lakshmi AG. In vitro anti-inflammatory activity of Aervalanata. Int J Physical Ther Rehabilitation 2015;7:57-9.

11. Ranjit Thakur. Study of antioxidant, the antibacterial and antiinflammatory activity of cinnamon (Cinamomum tamala), ginger (Zingiber officinale) and turmeric (Curcuma longa). Am J Life Sci 2013;1:273-7.

12. Maliheh NB, Prakash HS. Antioxidant and anti-inflammatory potential of selected medicinal plants of lamiaceae family. Int J Pharm Pharm Sci 2014;5(Suppl 1):100-4.

13. Muruganantham N, Solomon S, Senthamilselvi MM. The antioxidant and anti-inflammatory activity of Plumeriarubra (Flowers). Int J Pharm Sci Rev Res 2015;30:132-5.

14. Chaudhari MG, Joshi BB, Mistry KN. In vitro anti-diabetic and Anti-inflammatory activity of stem bark of Bauhinia purpurea. Bull Pharm Med Sci 2013;1:139-50.

15. Madduluri S, Sitaram B, Balasekharan C. In vitro evaluation of anti inflammatory activity of methanolic and ethanolic leaf extracts of five Indigenous plants in South India. Int J PharmTech Res 2014;6:569-74.

16. Kumar KP, Vadite SN, Chandra VB, Lavanya R, Kumar KN, Bhagyasree V. et al. Evaluation of in vitro and in vivo antiinflammatory activity of aqueous extract of Gliricidiasepium flowers in rats. Int J Pharm Pharm Res 2014;6:477-81.

17. Kalaiarasan A, Ahmed AJ. In vitro screening for antiinflammatory activity of Bulbophyllum kaitense. Rechib. Pseudobulb extract by HRBC method Eastern peninsular flora in South India. Int J Sci Res Publications 2012;2:1-5.

18. Gangabhavani K, Ravishankar K. Evaluation of analgesic and antiinflammatory activities of ethanolic extract of whole plantJusticiabetonica. World J Pharm Pharm Sci 2013;2:5218-28.

19. Gadamsetty G, Maru S, Sarada NC. Antioxidant and antiinflammatory activities of the methanolic leaf extract of traditionally used medicinal plant Mimusopselengi L. J Pharm Sci Res 2013;5:125-30.

20. Rao BG, Rao PU, Rao ES, Rao TM, Praneeth VSD. Evaluation of in vitro antibacterial activity and anti-inflammatory activity for different extracts of Rauvolfiatetraphylla L. root bark. Asian Pac J Trop Biomed 2012;2:818-21.

21. Mali AA, Hivrale MG, Bandawane DD, Chaudhari PD. Study of anti-inflammatory activity of Cassia auriculata linn. leaves in wistar rats. Indian Drugs 2012;49:44-7.

22. Malviya KG, Shivhare UD, Srivastav P, Shivhare SC. Evaluation of anti-inflammatory potential of Cyathoclinelyrata cass plant extract by using carrageenan induced and formalin induced rat paw edema. Asian J Res Pharm Sci 2013;3:90-4.

23. Azad AK, Azizi WSW, Babar ZM, Labu ZK, Zabin S. An overview on Phytochemical, anti-inflammatory and anti-bacterial activity of Basellaalba leaves extract. Middle-East J Sci Res 2013;14:650-5. 
24. Nwaehujor CO, Igile GO, Ode JO, Udegbunam RI. Antiinflammatory activities of methanol leaf extract of Brideliamicrantha (Hochst) Baill. (Euphorbiaceae) n Wistar Rats. J Appl Pharm Sci 2014;4:68-73.

25. Chhabra GS, Kulkarni KS. Evaluation of anti-inflammatory activity of Vitexagnuscastus leaves the quantitative analysis of flavonoids as possible active constituents. J Pharmacogn Phytochem 2014;3:183-9.

26. Anamul Haque, Afrina Zaman, Tahmina, Motaher Hossain, Icha Sarker, SaifulIslam, et al. Evaluation of analgesic, antiinflammatory and CNS depressant potential of Dendrophthoefalcata (Linn.) leaves extracts in experimental mice model. Am J Biomed Sci 2014;6:139-56.

27. Devi VA, Arumugasamy KA, Shalimol A, Kumar RN, Udhayasankar MR, Kokilavani R. Anti-inflammatory activity of Smilax wightii fruit endemic(Smilacaceaea)-an endangered medicinal plant from the Nilgiris. Asian J Pharm Biol Res 2014;2:136-8.

28. Gupta D, Verma N, Das HR, Gupta RK. Evaluation of antiinflammatory activity of Dracaena cinnabari Balf resin. Indian J Nat Prod Res 2014;5:215-22.

29. Gupta V, Chauhan S, Prakash A, Mathur A. Evaluation of in vitro and in vivo anti-inflammatory activities of Partheniumcamphora. Recent Res Sci Technol 2013;5:33-9.

30. Hafeez A, Jain U, Sajwan P, Srivastava S, Thakur A. Evaluation of carrageenan induced anti-inflammatory activity of ethanolic extract of the bark of Ficusvirens Linn. in swiss albino mice. J Phytopharmacol 2013;2:39-43.

31. Hosahally RV, Seru G, Sutar PS, Joshi VG, Sutar KP, Karigar AA. Phytochemical and pharmacological evaluation of Tragiacannabina for anti-inflammatory activity. Int Curr Pharma J 2012;1:213-6.

32. Sivagnanam I, Kalaivanan P, Rajamanickam M. Evaluation of antibacterial, analgesic and anti-inflammatory activities of oncocalyxone an isolated from Prenanthessarmentosus. J Appl Pharm Sci 2014;4:88-91.

33. Aher AN, Pal SC, Muke SA. An analgesic and anti-inflammatory activities of Ixoracoccineaflower. Indian Drugs 2013;50:64-7.

34. Jain G, Pandit D, Gupta P, Jharia V. Evaluation of antiinflammatory activity of aeeds of Melia azedarach (Linn.) in albino wistar rats. Int J Sci Eng Res 2015;6:1837-46.

35. Kamurthy H, Nampally S, Dontha S. Anti-inflammatory activity of Rotulaaquatica Lour. in albino rats. Int J Pharm Sci Drug Res 2014;6:48-51.

36. Katiyar NS, Rao NV, Gangwar AK. Evaluation of antiinflammatory activity of stem extracts of Cuscutareflexa (Roxb) in rats. Int J Res Pharm Biomed Sci 2012;3:1805-8.

37. Phraepakaporn K, Somsakul PW, Ampai P. Evaluation of antiinflammatory, analgesic, and antipyretic activities of the ethanol extract from Murdannialoriformis (Hassk.) Rolla Rao et Kammathy. Biol Impacts 2014;4:183-9.
38. Matthew S, Jain AK, James M, Matthew C, Bhowmik D. Analgesic and anti-inflammatory activity of i (Lam.) Pers. J Med Plants Stud 2013;1:24-8.

39. Mishra US, Murthy PN, Parida SK. Analgesic and anti-inflammatory activities of Indian medicinal plant Ziziphusxylopyrus stem barks in experimental animal models. Elixir Pharm 2012;44:7265-70.

40. Neha MPV, Suganthi V, Gowr S. Evaluation of anti-inflammatory activity in an ethanolic extract of Coriandrum sativum L. using carrageenan induced paw oedema in albino rats. Pharm Chem 2013;5:139-43.

41. Mollika S, Islam Na, Nasima P, Kabir A, Sayem W, Luthfunnesa, Saha Rony. Evaluation of analgesic anti-inflammatory and CNS activities of the methanolic extract of Syzygiumsamarangense leave. Global J Pharmacol 2014;8:39-46.

42. Mondal S, Raja S, Prasad PNVSS, Padilam S. Investigation of phytochemical, analgesic, anti-inflammatory and antipyretic effects of the Ixorapavettaandrews leaf. J NPA 2014;27:20-7.

43. Mirje MM, Zaman SU, Ramabhimaiah S. Evaluation of the antiinflammatory activity of Ocimum sanctum Linn (Tulsi) in albino rats. Int J Curr Microbiol Appl Sci 2014;3:198-205.

44. Sindhu RK, Arora S. Anti-inflammatory potential of different extracts isolated from the roots of FicuslacorBuCH. HuM and Murrayakoenigii L. Spren. Arch Biol Sci Belgrade 2014;66:1261-70.

45. Patel S, Rathod H, Kabra M, Vaishnav M. Evaluation of anti inflammatory activity of Hydroalcoholic leaves extracts of a polyherbal combination of Vitexnegundoand Murrayakoenigii against carrageenan induced paw edema in rats. J Mol Pharm Org Proc Res 2014;2:119.

46. Sithara AP, Ravi M, Mallya S, Sudhakara, Bairy S, Srikanth P, et al. Experimental evaluation of analgesic and anti-inflammatory potential of leaves of Antidesmamenasu on wistar albino rats. Int J Pharmacol Clin Sci 2013;2:105-12.

47. Kumar CNS, Das A, Arun RGR. Anti-inflammatory activity of Sapinduslaurifolius leaf extract in wistar rats. J Med Plants Stud 2014;2:1-5.

48. Jayaseelan M, Arumugam T, ThangarajN. Evaluation of antioxidant and anti-inflammatory activities of Corallocarpusepigaeus (Hook. F.) rhizomes. Int J Pharm Biomed Res 2014;5:18-24.

49. Umamageswari MS, Maniyar Y. Evaluation of anti-inflammatory activity of aqueous extract of leaves of Solanum melongena Linn. in experimental animals. J Clin Diagn Res 2015;9:1-3.

50. Nasreen S, Radha R. Assessment of quality of Withania Somnifera dunal (Solanaceae) pharmacognostical and phytophysicochemical profile. Int J Pharm Pharm Sci 2011;3:152-5.

51. Dr Vasant L. Ayurveda: The science of self healing. First Edition: Delhi; 1994. p. 18.

\section{How to cite this article}

- $\quad$ Karale Pushpa, Karale Mahesh. An overview on plants with antiinflammatory potential. Int J Curr Pharm Res 2017;9(5):1-4. 